\title{
DECORATIVE VALUES OF SELECTED CULTIVARS OF CLIMBING ROSES (ROSA L.) WITH REGARD TO THERMAL CONDITIONS
}

\author{
Zofia Włodarczyk, Agnieszka Perzanowska
}

\author{
Department of Ornamental Plants, Agricultural University in Kraków, Al. 29 listopada 54 \\ 31425 Kraków, e mail: zwlodarczyk@poczta.fm
}

Received: 29.01.2007

\begin{abstract}
S u m m a r y
In the years 20042006 in Kraków, phenological obser vations of climbing roses were conducted in order to determine the length and dates of their flowering period. The diameters of their flowers were also compared. Eight flowering repeating cul tivars were selected for the experiment: 'Climbing Souvenir de la Malmaison', 'Dortmund', 'Golden Showers', 'Goldstern', 'New Dawn', 'Parade', 'Sympathie' and 'White New Dawn'. During the studies, the shrub roses were not artificially watered in order to create conditions similar to those prevailing in public green areas. It was observed that irrespective of the air temperature pat tern in a given year, the studied cultivars did not bloom before 15 June. In 2006 high temperatures (above $20^{\circ} \mathrm{C}$ ), which continued throughout the whole flowering period, caused its shortening, and the interval between the first and the next flowering in the season lasted longer than in the previous years. In the years 20042006 , the cultivar 'New Dawn' bloomed the longest. In 2005 the studied cultivars produced larger flowers than the next year. The cultivars 'Dortmund' and 'White New Dawn' were characterised by the smallest diameter of flowers, whereas 'Climbing Souvenir de la Malmaison', 'Golden Showers' and 'Parade' were marked by the largest diameter.
\end{abstract}

Key words: phenology, flowering, Rosa, climbing roses, thermal conditions

\section{INTRODUCTION}

The decorative value of shrub roses is determined by the length and abundance of flowering, as well as the appearance of a single flower. These traits of specific rose cultivars are valuable for designers of home gardens and public green areas. In available Polish, European and American literature, large inaccuracies and discrepancies are noticeable in the presentation of the parameters defining the decorative value of climbing rose cultivars. Furthermore, it happens that authors, when describing a cultivar, do not give all important features omitting, e.g., the identification of the flowering pattern (which can be continuous, intermittent or once-only during the vegetation), the length and abundance of flowering, flower fullness, etc. Studies were undertaken on climbing rose cultivars popular in Poland and one cultivar belonging to strong-scented old Bourbon roses, 'Climbing Souvenir de la Malmaison', in order to verify and systemise information relating to the decorative features of these roses.

\section{MATERIAL AND METHODS}

Observations were conducted in the southern part of Kraków, in a private rose collection of the author of this paper. The object of the study were several-year-old shrubs of repeating flowering climbing roses grafted on multiflora rose (Rosa multiflora Thunb.) rootstocks. Eight cultivars of rose (Rosa L.) were observed: 'Climbing Souvenir de la Malmaison', 'Dortmund', 'Golden Showers', 'Goldstern', 'New Dawn', 'Parade', 'Sympathie' and 'White New Dawn'. A single experiment included four shrubs of each cultivar growing by arch-shaped metal structures $1.1 \mathrm{~m}$ wide and $2.2 \mathrm{~m}$ high. In early spring, the shrub roses were pruned, removing the frost affected parts. In 2005 and 2006, due to severe damage of the shoots by frost down to the boundary of the winter cover, the cutting was made at a height of $15 \mathrm{~cm}$ above the substrate surface (in the cultivar 'Climbing Souvenir de la Malmaison' only in 2006). After the first flowering, dead inflorescences were removed. In the experiment, artificial watering was not used in order to create for the plants conditions similar to those prevailing in public green areas in Poland.

The observations were conducted in the years 2004-2006 from early spring (April) until the time when buds and flowers were damaged by low temperature. The dates of phenological occurrences were recorded every 6-8 days. In the experiment, special attention was paid 
to the dates and length of the flowering period in correlation to thermal conditions prevailing in a given year.

At the site where the experiment was conducted, air temperature measurements were also made using the HOBO recorder.

The flowering length of the particular cultivars and weekly average air temperatures, as well severe ground frosts $\left(-4^{\circ} \mathrm{C}\right.$ and more) in the years $2004-2006$ are shown on the chart. The flowering stage is presented by means of bars the beginning of which indicates the start of flowering (flowers are on $10 \%$ of shoots on a shrub), and its end - the end of flowering (the last $10 \%$ of shoots on a shrub have flowers).

Measurements of the diameter of flowers of the studied cultivars were made in the years 2005 and 2006. The flowers measured were at full bloom stage, when the corolla petals were wide open, the stamens visible, and the colour of the petals intensive (proper for the respective cultivar). Twenty five petals of each cultivar were measured in four replicates. The measurement results were processed statistically using the variance analysis method, and the means were compared using the t-Duncan test (the significance level of 0.05).

\section{RESULTS}

In the first quarter of 2004, the lowest air temperatures were recorded at the beginning of March, and they were about $-16^{\circ} \mathrm{C}$. In the next two years, temperatures were much lower (about $-29^{\circ} \mathrm{C}$ ), and their occurrence was noted in the third decade of January. In 2004 the snow cover persisted until 1 February, and in 2005 - until 16 March, whereas in 2006 snow melted as late as $25 \mathrm{March}$. The last severe (about $-4^{\circ} \mathrm{C}$ ) spring

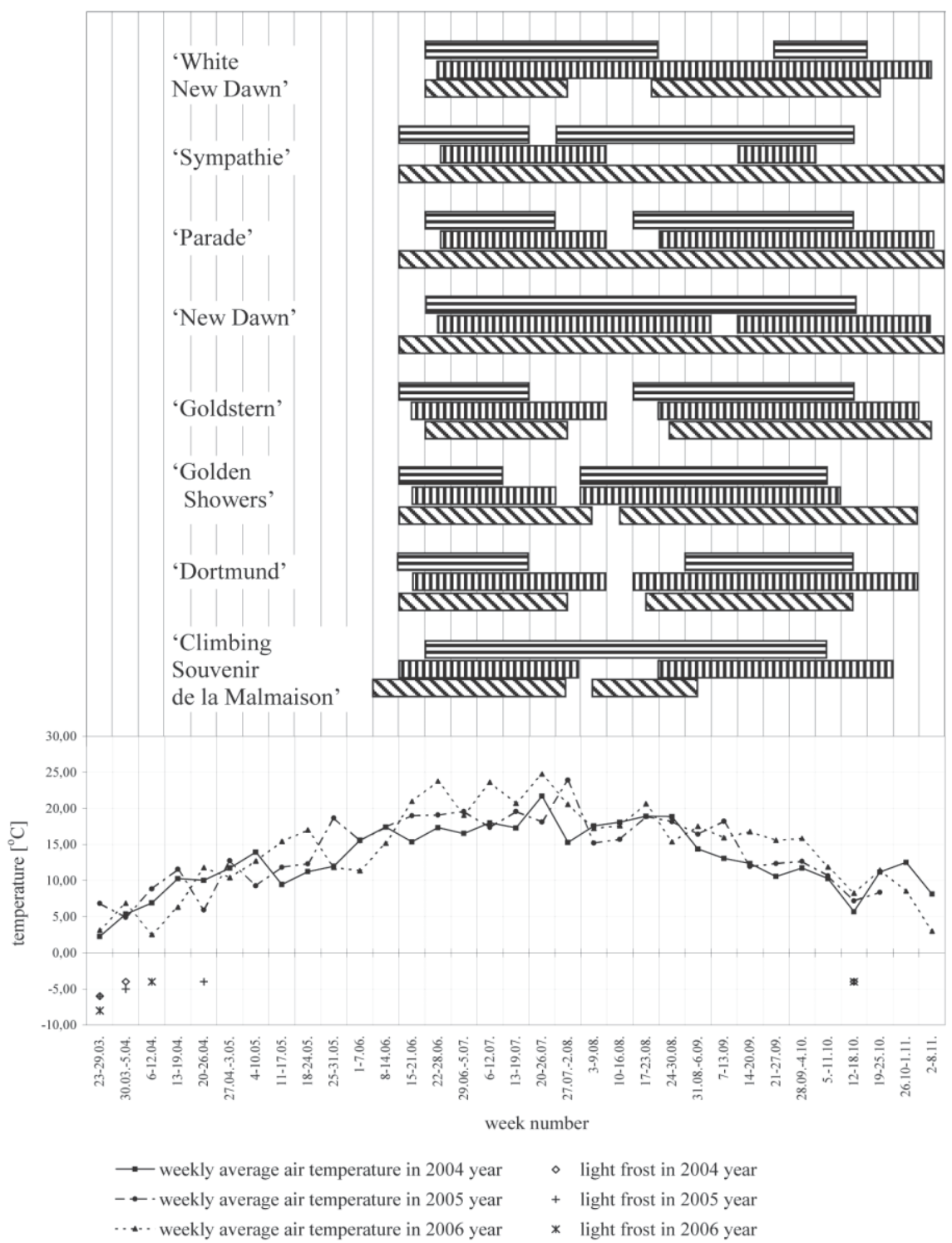

Figure 1. Dates of flowering of selected climbing rose cultivars in the years 20042006 with regard to thermal conditions at the site of the experiment. 


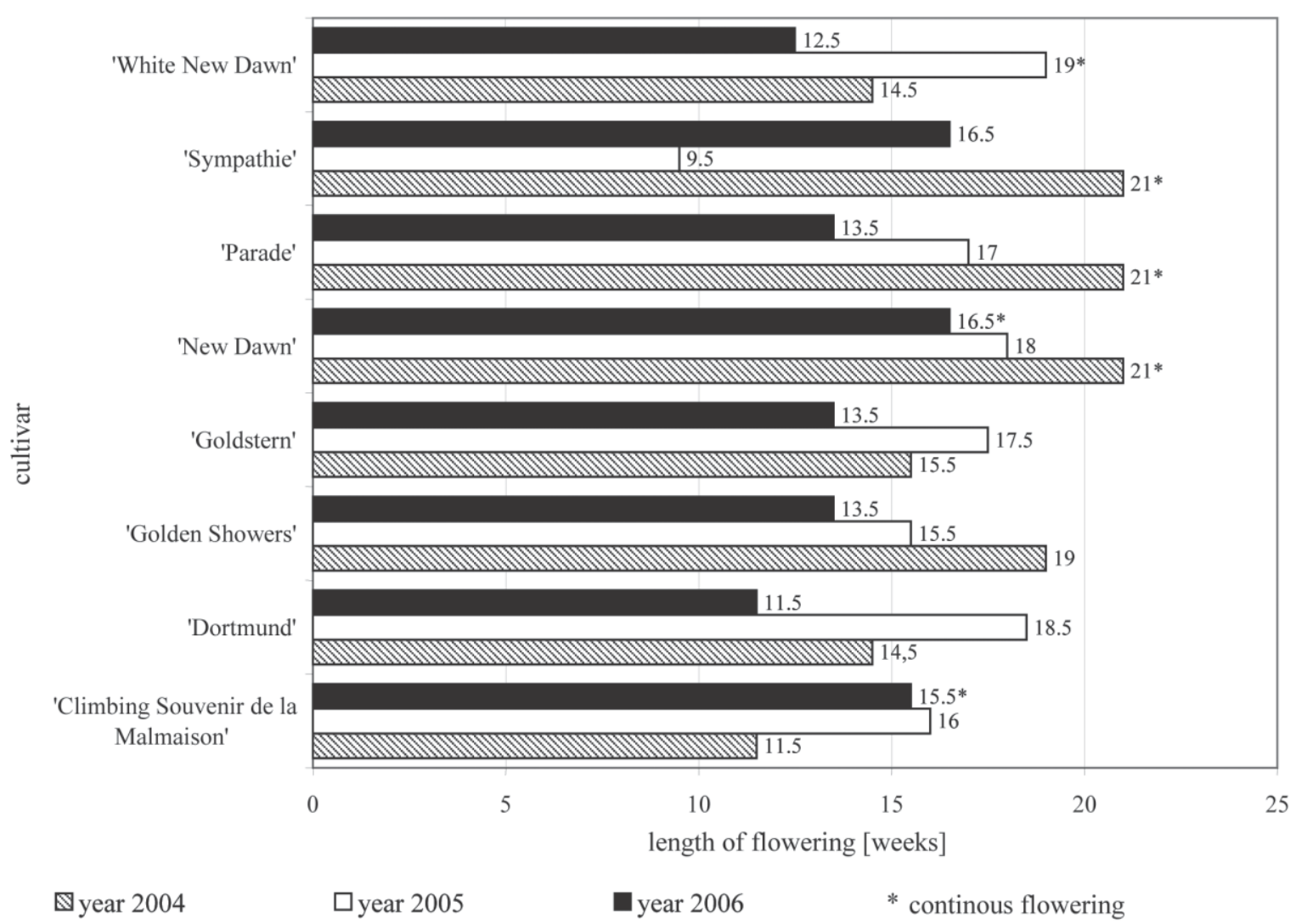

Figure 2. Total length of the flowering period of selected climbing rose cultivars in the years 20042006.

ground frost in 2004 occurred at the turn of March and April, and in 2005 in the third decade of April, whereas in the next year in the first decade of April. The condition of the shrubs after the winter in the years 2005 and 2006 was much worse compared to the first year of observation.

In 2004 spring cooling occurred in the middle of May, in 2005 - at the beginning of May, whereas in 2006 - as late as the beginning of June (however, it did not cause a delay in flowering of the studied rose cultivars compared to the previous years).

Irrespective of the air temperature pattern, in the all the years of observation, the latest flowering (between 22 and 28 June) cultivar was 'White New Dawn' (Fig. 1). The other cultivars bloomed around 15 June or up to 10 days later. The cultivar 'Climbing Souvenir de la Malmaison' behaved exceptionally in 2004, since the flowering of this cultivar started as early as 8 June. In 2005 most of the studied cultivars (except for 'Goldstern') bloomed by about $0.5-1.5$ week later than in the previous year.

In 2006, in the period from the end of June until the end of July, air temperatures were much higher than in the previous years, what caused the shortening of the first flowering in most of the studied cultivars. Only rose 'New Dawn' and the cultivar 'White New Dawn', originating from it, continued the flowering throughtout the next weeks. The cultivar 'Climbing Souvenir de la
Malmaison' behaved similarly, but its flowering after 12 July, when the average air temperature was $23.5^{\circ} \mathrm{C}$, was not so abundant any more.

In all the years of observation, the cultivars 'Dortmund' and 'Goldstern' interrupted the flowering after about one week from the occurrence of weekly average air temperatures in the range of $22-24^{\circ} \mathrm{C}$.

In the cultivars in which two flowerings occurred in the season, the longest flowering intervals, lasting from 3 up 6 weeks, were observed in 2006. In 2005 they lasted from 1 up to 3 weeks, and in 2004 only one week longer.

The end of the last flowering in the season was caused by the occurrence of unfavourable thermal conditions. Severe ground frosts (from $-4^{\circ} \mathrm{C}$ ) did not damage only green buds whose sepals tightly adhere to each other. During the other growth stages, the buds and flowers, as a result of such a low temperature, lost their decorative values and died off. In the years 2004 and 2006, between 12 and 18 October, severe ground frost occurred $\left(-4^{\circ} \mathrm{C}\right)$. However, in 2004 it did not cause the end of flowering. The shrubs in this year were in a better condition and they had much longer shoots, compared to the years 2005 and 2006, since they had not been affected by frost during the winter. In connection with that, the flowers were located higher above 


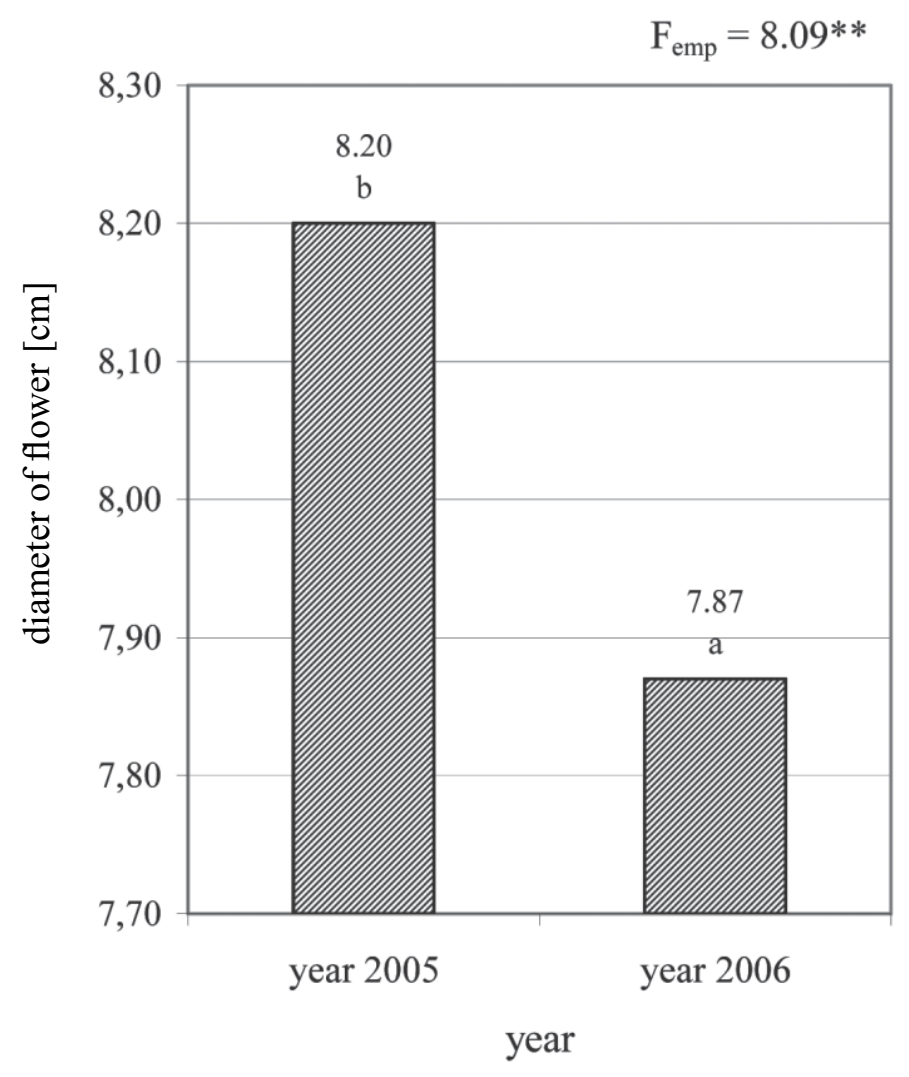

Figure 3. Diameter of flowers of selected rose cultivars in the years 20052006 depending on the year (values marked with the same letters do not differ significantly).

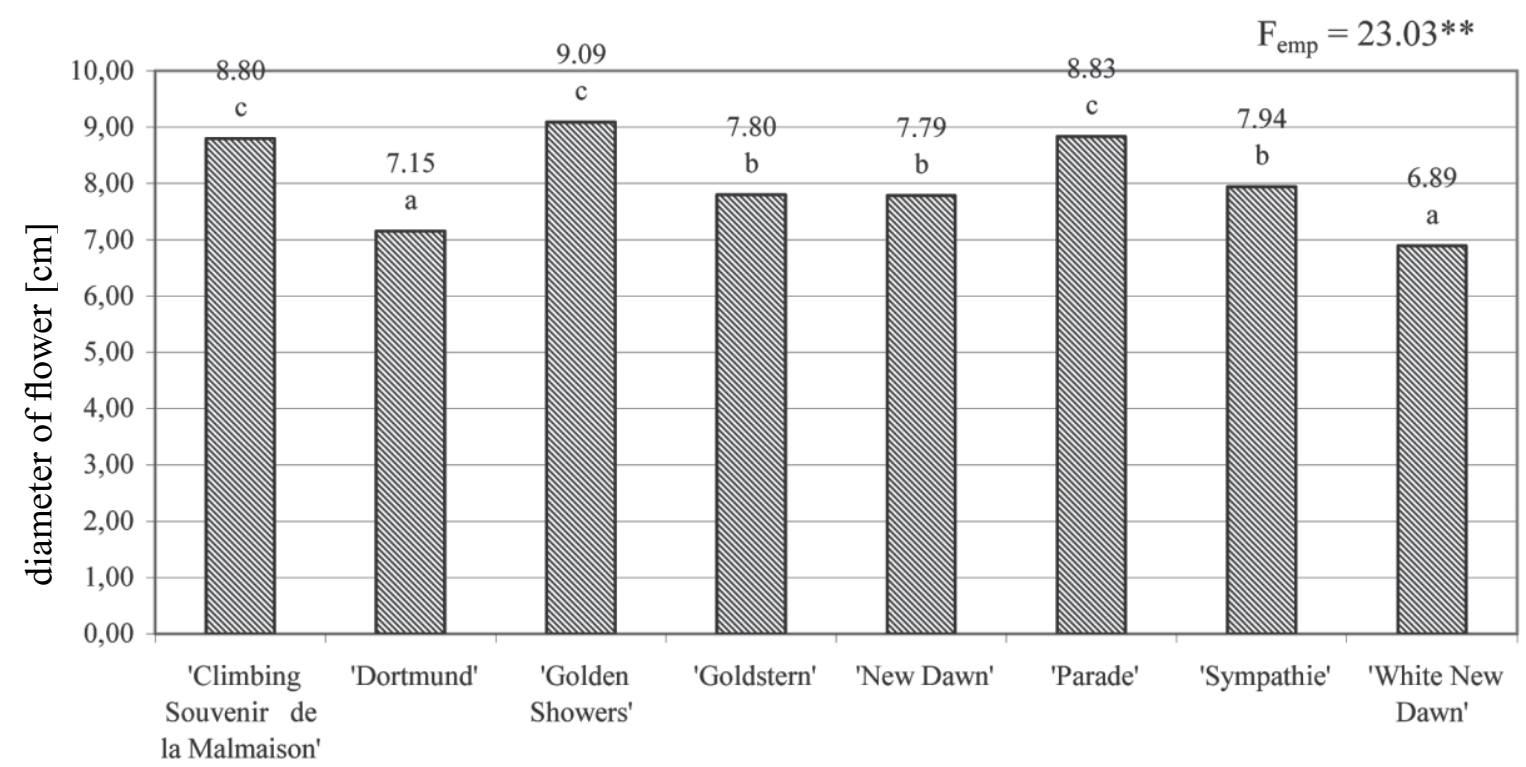

cultivar

Figure 4. Diameter of rose flowers in the years 20052006 depending on the cultivar (values marked with the same letters do not differ significantly). 
the soil surface and they were not so exposed to the effect of ground frost as in the next years. The temperature increase up to $11^{\circ} \mathrm{C}$ in the next weeks enabled the further development of the flower buds and the extension of flowering until the end of October, and even the beginning of November.

In 2005, until 25 October, such low temperatures did not occur and the flowering lasted until the end of that month. In 2006, after the occurrence of severe ground frost, the flowering ended.

The length and dates of flowering of the studied rose cultivars also depend on the conditions of the shrubs after winter. In the years 2005 and 2006, when all the the years 2004 and 2006, and in 2005 there was only a one-week flowering interval. In the studied cultivar, the flowering lasted from 16.5 up to 21 weeks (Fig. 2).

When comparing the results of measurements of the diameter of flowers, it was found that in 2005 flowers of the studied cultivars were significantly larger than the year later (Fig. 3). There were significant differences in the size of flowers between the particular cultivars. The cultivars 'Dortmund' and 'White New Dawn' were characterised by the smallest diameter of flowers (Fig. 4), whereas the cultivars 'Climbing Souvenir de la Malmaison', 'Golden Showers' and 'Parade' had the significantly largest flowers.

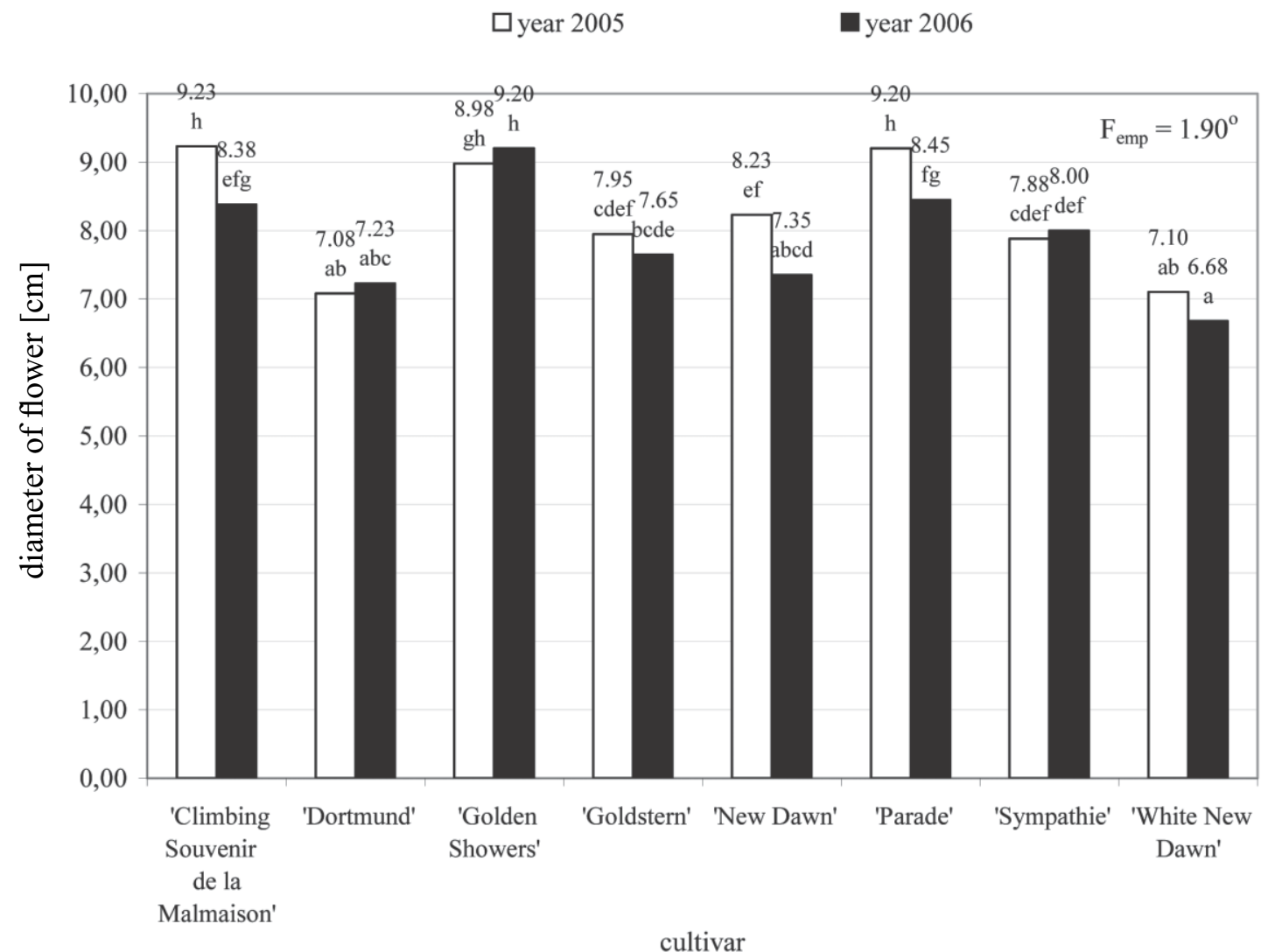

Figure 5. Diameter of flowers of selected climbing rose cultivars in the years 20052006 (values marked with the same letters do not differ significantly).

rose shoots were affected by frost down to the boundary of the winter cover and it was necessary to carry out heavy pruning in the spring, the flowering of the cultivars 'Golden Showers', 'Parade' and 'Sympathie' was much shorter than in the first year of observation. In 'Climbing Souvenir de la Malmaison', heavy spring pruning, made in 2006 , delayed the flowering from 1 up to 2 weeks compared to the previous years.

Over the three years of observation, 'New Dawn' proved to be the most relable cultivar in which flowers appeared continuously from June until autumn in
When analysing the cultivar factor and the year in which the measurements were made, it was found that the significantly smallest flowers were produced by the cultivar 'White New Dawn' in 2006 (Fig. 5), whereas flowers of the cultivars 'Golden Showers' were characterised by the largest diameter in both years of observation, and in 2005 flowers of the cultivars 'Climbing Souvenir de la Malmaison' and 'Parade'. No significant differences were observed between the size of flowers of the other rose cultivars. 


\section{DISCUSSION}

There are many discrepancies between the obtained results relating to the length and dates of flowering of the studied cultivars and information contained in available publications. Only in the case of 'Golden Showers' and 'Goldstern', the results match the authors' opinions. The cyclicity of flowering is discussed by Krüssmann (1986), Frazik-Adamczyk (2004) and Chojnowska (2004). Similar opinions on 'Golden Showers' are expressed by Haenchen and Haenchen (1980), Harkness (1993), Wiśniewska-Grzeszkiewicz (1998), Markley (2000), Ciesielski and Wybicki (2003), Quest-Ritson (2003), Czekalski (2005) and Monder (2006). Monder (2002) and Quest-Ritson (2003) also inform about the cyclicity of flowering of the cultivar 'Goldstern'. As shown by the studies, this rose starts flowering in the second half of June, what is consistent with the opinion of Frazik-Adamczyk (2004).

In the case of rose 'Dortmund', most authors report that it repeats flowering (Kordes, 1960; Krüssmann, 1986; Markley, 2000; Monder, 2006). It was confirmed by the observations conducted. Only Frazik-Adamczyk (2004) reports that 'Dortmund' blooms continuously from mid-June until the end of September. The start date of flowering is consistent with the opinion of the author, however, over the three years of observation, the studied cultivar bloomed until mid-October or longer.

Opinions of authors are divided over the problem of flowering of the remaining four cultivars studied. Based on the obtained results, it was found that, depending on the condition of a shrub in a given year, the flowering of 'Climbing Souvenir de la Malmaison', 'New Dawn', 'Parade', 'Sympathie' and 'White New Dawn' is intermittent or continuous. But a part of authors report that a given cultivar blooms continuously, whereas the others inform that the flowering is intermittent. In the case of rose 'Parade', authors of publications unanimously claim that it blooms continuously (Schultheis, 2003; Quest-Ritson, 2003; Frazik-Adamczyk, 2004). But no information has been found that this cultivar may bloom intermittently. As reported by QuestRitson (2003) and Frazik-Adamczyk (2004), rose 'Parade' blooms from mid-June until ground frost, what is consistent with the observations conducted.

In the case of the cultivar 'Climbing Souvenir de la Malmaison', no information has been found that it may bloom continuously, what was observed in 2006. Both Schultheis (2003) and Quest-Ritson (2003) claim that the flowering of the studied cultivar is intermittent. Quest-Rits on (2003) adds that the first flowering in the season is more abundant than the next one, what was confirmed by the 2006 studies. The start date of flowering given by Schultheis (2003) is consistent with the obtained results.
Rose 'New Dawn' is commonly considered as a flowering repeating cultivar (Kordes, 1960; Glasau, 1961; Fuchs,1976; Večeřa, 1980; Haenchen and Haenchen, 1980; Jerzy et al., 1992; Harkness 1993; Buczacki, 1997; Markley, 2000; Ciesielski and Wybicki, 2003; Frazik-Adamczyk, 2004; Czekalski, 2005). However, Krüssmann (1986) and Monder (2006) claim that the flowering of this cultivar is continuous in the growing season. As reported by Jerzy et al. (1992), Schultheis (2003), Frazik-Adamczyk (2004) and Czekalski (2005), the start of flowering of the cultivar 'New Dawn' is in mid-June, what was confirmed by the studies conducted. The end of flowering occurs in October (Schultheis, 2003; Frazik-Adamczyk, 2004), what is consistent with the results obtained in 2006, whereas in the previous years this rose bloomed until the beginning of November.

Opinions of authors are also divided over the problem of flowering of the cultivar 'Sympathie'. Harkness (1993), Schultheis (2003) and Frazik-Adamczyk (2004) report that this rose blooms continuously, whereas Krüssmann (1986), Thalacker (1996), Monder (2006), Ciesielski and Wybicki (2003), Quest-Ritson (2003) oraz Czekalski (2005) claim that its flowering is intermittent. According to the studies conducted, the flowering of the cultivar 'Sympathie' starts in mid-June and lasts until October, and even November, what is consistent with the opinion of Schultheis (2003) and Frazik-Adamczyk (2004).

According to the opinion of Haenchen and Haenchen (1980), Monder (2006) and QuestRits on (2003), the cultivar 'White New Dawn' repeats flowering, whereas Frazik-Adamczyk (2004) reports that the flowering of this rose is continuous. The start date of flowering is consistent with the information given by Frazik-Adamczyk (2004).

Opinions of authors of publications relating to the diameter of flowers of the studied cultivars are very diverse. The measurements made indicate that flowers of most of the studied rose cultivars are smaller or their diameter is within the limits given by the authors of available publications, and in the case of the cultivar 'Golden Showers', the observation results exceed the maximum values given by some authors.

As reported by Quest-Ritson (2003), the diameter of flowers of the cultivar 'Climbing Souvenir de la Malmaison' is over $12 \mathrm{~cm}$, and of 'Parade' $-10 \mathrm{~cm}$, however, the studies conducted proved that their flowers are smaller.

The results obtained in the case of the cultivar 'Dortmund' match only the information given by Kächler and Schakat (1989), whereas according to Kordes (1960), Harkness (1993), Thalacker (1996), 
Quest-Ritson (2003) and Frazik-Adamczyk (2004), flowers of this cultivar are larger by $3-5 \mathrm{~cm}$.

The measurements made in rose 'Golden Showers' showed that the diameter of its flowers is $9 \mathrm{~cm}$; such a value is also given by Quest-Ritson (2003) and it is larger than the one given by Kordes (1960), as well Ciesielski and Wybicki (2003). But according to a part of authors (Kächler and Schakat, 1989; Frazik-Adamczyk, 2004; Czekalski, 2005), flowers of this cultivar reach the diameter from 10 up to 12 $\mathrm{cm}$, what is not consistent with the obtained results. The obtained values correspond only to the information given by Quest-Ritson (2003).

According to Ciesielski and Wybicki (2003), flowers of the cultivar 'Goldstern' reach the diameter from 7 up to $8 \mathrm{~cm}$, what is consistent with the measurements made. But Thalacker (1996) and Quest-Ritson (2003) report that flowers of this cultivar are much larger (from 10 up to $12 \mathrm{~cm}$ ).

Most authors (Kächler and Suhaka, 1989; Thalacker, 1996; Ciesielski and Wybicki, 2003; Frazik-Adamczyk, 2004) inform that the diameter of flowers of the cultivar 'New Dawn' ranges between 6 and $8 \mathrm{~cm}$. It is confirmed by the measurements made. But Jerzy et al. (1992) and Czekalski (2005) report that the diameter of flowers of the studied cultivar is 9 $\mathrm{cm}$, and according to Kordes (1960), it is even larger by $1 \mathrm{~cm}$.

In the case of the cultivar 'Sympathie', authors report that the diameter of its flowers ranges between 8 and $10 \mathrm{~cm}$ (Kächler and Schakat, 1989; Thalacker, 1996; Ciesielski and Wybicki, 2003; Frazik-Adamczyk, 2004; Czekalski, 2005). The values obtained in the experiment are approximate to the lower limit of this range.

Quest-Ritson (2003) reports that the diameter of flowers of the cultivar 'White New Dawn' is $7 \mathrm{~cm}$, what is consistent with the measurements made. But according to Frazik-Adamczyk (2004), flowers of this cultivar are larger by 1 up to $3 \mathrm{~cm}$.

\section{CONCLUSIONS}

1. In the years 2004-2006, irrespective of the thermal conditions pattern, the studied cultivars bloomed around 15 June or up to 10 days later. Exceptionally in 2004, the flowering of the cultivar 'Climbing Souvenir de la Malmaison' started a week earlier.

2. In 2006, as a result of the occurrence of high air tempreatures in the period from the end of June until the end of July, the flowering of most of the studied cultivar (with the excpetion of 'New Dawn' and 'White New Dawn') was shortened, and additionally, in the cultivars flowering twice in the season, the interval between the first and second flowering was longer than in the previous years.
3. In all the years of observation, the longest flowering cultivar was 'New Dawn' (from 16.5 up to 21 weeks), what makes it a valuable climbing rose cultivar in green areas.

4. In 2005 flowers of the studied rose cultivars were significantly larger than in 2006.

5 . The smallest diameter of flowers was found in the cultivars 'Dortmund' and 'White New Dawn', whereas the largest - in 'Climbing Souvenir de la Malmaison', 'Golden Showers' and 'Parade', and the knowledge of this trait has practical application in the creation of mixed-species plantings of these cultivars with other plants, when attention is paid not only to the colour of flowers, but also to their size.

\section{REFERENCES}

Buczacki S., 1997. Róże / Roses. Agencja ELIPSA, Warszawa: 63, 77, 114, 119, 122, 123.

Ciesielski M., Wybicki Z., 2003. Katalog roślin II. Drze wa, krzewy, byliny / Catalogue of plants II. Trees, shrubs, perennials. Red. Waszak A., Związek Szkółkarzy Pol skich, Warszawa: 114116.

Czekalski M., 2005. Liściaste krzewy ozdobne / Deciduous ornamental shrubs. PWRiL, Poznań: 126.

Frazik Adamczyk M., 2004. Ogrodowe pnącza / Garden climbers. Wydawnictwo „działkowiec” Sp. z o.o., War szawa: 103108

Fuchs H., 1976. Les roses de nos jardins. Editions floraisse, Antony: 136, 140.

Glasau F., 1961. Rosen im Garten ein buch für Rosenfreunde. Verlag Paul Parey, Hamburg und Berlin: 117, 118, 123.

Haenchen E., Haenchen F., 1980. Das neue Rosenbunch. VEB Deutscher Landwirtschaftsverlag, Berlin: 7476 , 102, 103.

Harkness P., 1993. Róże. Encyklopedia fotograficzna / Roses. Photographic encyclopaedia. MUZA S.A., Warszawa: $101,118,161,200,205,213$.

Jerzy M., Żyła S., Czekalski M., 1992. Róże / Roses. PWRiL, Warszawa: 211.

Kordes W., 1960. Das Rosenbuch. Verlag M.\&H.Schaper, Han nover: 252,256

Krüssmann G., 1986. Rosen, Rosen, Rosen. Verlag Paul Parey, Berlin: 345, 366, 367, 407, 413, 449.

Łukasiewicz A., 1984. Potrzeba ujednolicenia metodyki feno logicznej w polskich ogrodach botanicznych i arboretach / The need to harmonise the phenological methodology in Polish botanical garden and arboreta. Wiad. Bot., 28 (2): 153158.

Markley R., 2000. Róże. Poradnik praktyczny / Roses. Practi cal handbook. Bertelsmann Media Sp. z o.o. Świat Książ ki, Diogenes, Warszawa: 20, 22, 28 29, 38.

Monder M., 2006. Róże / Roses. PWRiL, Warszawa: 79, 83.

Quest Ritson C.\&B., 2003. Encyclopedia of roses. The Ameri can Rose Society. DK Publishing, Inc., New York: 123, 125, 175, 177, 296, 374, 388, 420. 
Schultheis H., 2003. Róże w ogrodzie. Pielęgnacja i odmiany / Roses in a garden. Culture and cultivars. Świat Książki, Warszawa: 54, 55, 139, 141.

Thalacker B., 1996. Kreuzer's Gartenpflanzen Lexikon. Verlag Postfach, Wien: 136.

Večeřa L., 1980. Mały atlas róż / Little atlas of roses. PWRiL, Warszawa: 176.

Wiśniewska Grzeszkiewicz H., 1998. Róże / Roses. Polski Związek Działkowców Krajowa Rada, Warszawa: 82.

\section{Walory dekoracyjne wybranych odmian róż pną- cych (Rosa $\mathrm{L}$.) z uwzględnieniem warunków termicznych}

\section{Streszczenie}

W latach 2004-2006 w Krakowie prowadzono obserwacje fenologii róż pnących w celu określenia długości oraz terminu ich kwitnienia. Porównano także średnice ich kwiatów. Do doświadczenia wybrano osiem odmian powtarzających kwitnienie: 'Climbing
Souvenir de la Malmaison', 'Dortmund', 'Golden Showers', 'Goldstern', 'New Dawn', 'Parade', 'Sympathie' i 'White New Dawn'. W czasie prowadzenia badań krzewy różane nie były sztucznie nawadniane, aby stworzyć warunki podobne do panujących $\mathrm{w}$ publicznych terenach zieleni. Zaobserwowano, iż bez względu na układ temperatur powietrza w danym sezsonie, badane odmiany nie zakwitały przed 15 czerwca. W 2006 roku wysokie temperatury (powyżej $20^{\circ} \mathrm{C}$ ) utrzymujące się przez cały okres kwitnienia spowodowały jego skrócenie, a przerwa pomiędzy pierwszym a kolejnym kwitnieniem w sezonie trwała dłużej niż w poprzednich latach. W latach 2004-2006 najdłużej kwitła odmiana 'New Dawn'. W 2005 badane odmiany wytworzyły większe kwiaty niż rok później. Najmniejszą średnicą kwiatów charakteryzowały się odmiany: 'Dortmund' i 'White New Dawn', natomiast największą - róże: 'Climbing Souvenir de la Malmaison', 'Golden Showers' oraz 'Parade'. 